\title{
СРПСКИ ЈЕЗИК НА ПУТУ КА ЕВРОПСКОЈ УНИЈИ
}

\begin{abstract}
Две године пошто је Република Србија званично добила статус кандидата за чланство у Европској унији и више од две деценије од највећег таласа проширења, дискурс о Европској унији и даље је актуелан, а у српски језик пристижу нови појмови махом преузети из енглеског као изворног језика или језика посредника. Циљ овог истраживања је да се утврди до које мере је просечан, образован и, мање или више, информисани говорник српског језика упућен у значење лексема, односно израза који се јављају у писаном и усменом дискурсу новијег доба, као и оних елемената који се већ могу сматрати устаљеним и у доброј мери одомаћеним у српском језику. На основу упитника, који је попунило 50 изворних говорника српског језика, може се закључити да се српски језик итекако мења у новијим друштвенополитичким околностима и да говорници активно учествују у тумачењу одређених појмова који, по свему судећи, још увек нису довољно јасни. Примећено је да су се поједине лексеме у довољној мери одомаћиле, али и да постоје оне које су скоро сасвим непознате говорницима иако је њихова употреба документована у више релевантних извора.
\end{abstract}

Кључне речи: српски језик, енглески језик, позајмљенице, језик посредник, дискурс о Европској унији, друштвено-политичке околности.

\section{Увод}

Зачеци Европске уније сежу у средину 20. века, у послератно време нових идеала о обнови и уједињењу народа који ће живети у миру и благостању. Много је времена прошло од 1950. године и познате Шуманове декларације којој ће уследити низ уговора који ће установити Унију онаквом каква јесте данас. Након друштвено-политичких превирања деведесетих година Србија је једна од само неколико земаља на Балкану које још увек нису постале чланице ове политичке и економске заједнице. Без жеље да улазимо у детаље у вези 
са односима Србије и Европске уније, ваљало би напоменути да се озбиљнији кораци ка Унији праве још 2008. године, када је потписан Споразум о стабилизацији и придруживању, чиме су се стекли услови да земља одлучно настави приближавање „европској породици”. Србија је у марту 2012. званично добила статус кандидата, а преговори су почели 21. јануара 2014. Поред тога, чињеница да је Хрватска постала пуноправна чланица јула 2013. говори у прилог томе да интеграција и даље траје и да ће се и Србија једног дана можда наћи у простору који је дуго прижељкивала.

Дугогодишње праћење овог процеса и извештавање медија о односима Србије и Европске уније учинили су да и обичан говорник српског језика примети да се нешто дешава са нашим матерњим језиком. Томе још више доприноси и брзи развој технологија које су омогућиле да се као никада пре информишемо о свим дешавањима помоћу корисног помагала без којег, чини се, тешко може да се опстане у савременом свету - енглеског језика. Дискурс о Европској унији подразумева и писане и усмене садржаје који се преносе путем званичних медија, али све више и преко развијених друштвених мрежа, а основно језгро овог дискурса је управо лексичка база англицизама који су се у тој мери проширили по језицима Европе да изворни говорници често и не примећује страни карактер тих позајмљеница. Српски језик није усамљен случај у том смислу, јер и други, утицајнији језици тешко одолевају приливу англицизама. Чини се да се овде ради о питању опште културе и обавештености те се сматра нормалним, ако не и нужним, одржавати корак са трендовима, па тако и новим појмовима.

Циљ овога рада био је да се испита колико „нове терминологије“ везане за процес придруживања Србије Европској унији има у српском језику и да ли просечан изворни говорник осећа да се нешто збива са нашим језиком. Посебно смо желели да испитамо реакције и ставове изворних говорника српског језика према оваквом дискурсу.

\section{Кључни појмови}

Истраживање се може подвести под окриље теорије језичких контаката (Вајнрајх 1953; Хауген 1954; Филиповић 1986) јер је предмет истраживања управо однос српског језика и елемената страног језика, тачније англицизама. 
У оквиру теорије језичких контаката или контактне лингвистике (Филиповић 1986; Хауген 1954) ,језичко посуђивање” представља процес у коме језик давалац „даје” материјал језику примаоцу. Овај процес подразумева прелазак моgела из језика даваоца у језик прималац, при чему модел представља оригинални израз који почиње своју трансформацију, односно прилагођавање систему у који улази. У овом процесу, елемент из једног језика пролази кроз различите стадијуме адаптације и на самом крају потпуно се интегрише у језички систем језика примаоца, па постаје оно што се у теорији језичких контаката назива рейликом. Током дифузије, односно позајмљивања, како тврди Филиповић (1986: 38) постоје три корака - пребацивање, односно прекључивање кодова, када се два језика користе наизменично или се реч преузима у изворном облику; интерференција - када долази до преклапања два језика, док на крају следи интеграција. Преношење одређених аспеката модела на реплику назива се линївисиичкка инйерференција, а њен ниво одражава се у степену интеграције одређеног језичког елемента у језику примаоцу. На једном крају биће нулти ступањ интеграције, када је језички елемент из језика даваоца преузет у свом изворном облику, а на сасвим другом крају биће модели који су се потпуно интегрисали и преузели све карактеристике језика примаоца. Хауген (1954) говори о супституцији, односно процесу замене аспеката модела елементима из језика примаоца, и импортацији као супротном процесу који подразумева сваки елемент модела који је преузет од стране реплике. Адаптација неког облика може бити примарна и секундарна, и формална и садржинска, при чему су укључени сви језички нивои - ортографски, фонолошки, морфосинтаксички, семантички и прагматички. Примарна адаптација се дешава док модел постаје део новог језика, а секундарна адаптација наступа пошто је модел већ постао део језика примаоца и у оквиру потоње стварају се нови облици или значења у језику примаоцу. Дешава се и да се реч не преузима директно из језика даваоца, па се тада говори о језику посреднику у коме је реч већ коришћена као позајмљеница (Филиповић 1986: 26). Ово је чест случај са енглеским језиком који је као линіва франка довољно утицајан да служи као језик посредник позајмљеницама које су изворно, на пример, из француског језика.

Језички пуристи са неодобравањем гледају на позајмљивање страних језичких елемената, али чињеница је да, ако постоји празнина 
у вокабулару и реална потреба за новим речима да се изразе нови појмови, онда је један од начина попуњавања оваквих празнина управо позајмљивање (Филиповић 1986: 193). У нашем истраживању посматрали смо речи које су махом англицизми. Међутим, треба правити разлику између анїлицизама и йсеуgоанїлицизама који настају од елемената енглеског порекла, али целина коју чине није преузета из енглеског јер у њему не постоји (Филиповић 1986: 193), као што су іолман или иеенисер. Прћић (2005: 59) наводи две врсте англицизама. Терминолошки гледано, англицизми су опште речи или везане морфеме из енглеског језика које се користе у српском у мање или више адаптираној форми. Међутим, у ширем смислу овај термин може се односити и на реч, фразу или реченицу у српском језику у којој се огледа норма енглеског језика са неког од језичких нивоа (колокације, цели искази).

Разни су разлози преузимања англицизама, а међу њима је и жеља да се што пре нађе одговарајућа реч за нови појам у спрези са страхом да српска реч није дорасла том задатку (Васић, Прћић и Нејгебауер 2011: 7). На истом месту Васић, Прћић и Нејгебауер подсећају да „у дневној штампи и политичком језику имйлеменйација успешно потискује сйровођење и реализащију". Морамо рећи да наши подаци указују на промену у употреби ове лексеме јер више од пола испитаника користи домаће речи сировођење (13) ${ }^{1}$ и иримена (16). Занимиљиво је приметити да се међу јединицама које које смо изабрали за тестирање, само једна могла наћи у Речнику новијих анїличизама (2011) горепоменуте групе аутора. То је управо имйлеменииација, која је у овом речнику дефинисана као „спровођење у дело неког званичног споразума или одлуке = спровођење, = реализација". Прћић (2005: 56) управо ову реч узима за пример инериијскоі синонима, тј. лексеме преузете из другог језика са њеним изворним значењем, без размишљања да ли у језику примаоцу постоји реч истог или сличног значења.

Прћић (2005: 11-15) говори о ,језичкој англоглобализацији”, односно масовној употреби енглеског језика и тамо где би англицизми могли бити природно замењени домаћим материјалом, а енглеском приписује статус „одомаћеног страног језика”. Оно што издваја ен-

1 Број испитаника писаћемо у округластим заградама. 
глески од осталих страних језика, према речима овог аутора, јесте његова доступност, која га чини језиком који је нешто више од страног - он постаје „допунски језик” јер врши сталан утицај на међународну заједницу и делује чак и на оне који га не знају или не усвајају у оквиру образовног система. Из овога следи да се енглески посматра као ствар престижа и као нешто што се подразумева као део опште културе. Проблем који се јавља управо због оваквог карактера енглеског језика јесу позајмљенице које се све више преузимају са минималним изменама, дакле само формално, док садржина остаје недовољно јасна или неутврђена (Прћић 2005: 25).

\section{Метод истраживања}

Истраживање је спроведено на групи од 50 испитаника различитог пола, старости и образовања у жељи да се добију што репрезентативнији и релевантнији подаци о реалном стању српског језика. Упитник (видети Додатак) се састоји од 20 питања раличитог типа. Коришћена су питања са понуђеним одговорима и отворена питања, која су се показала веома корисним, јер смо добили податке који доста говоре о језичким ставовима и понашању појединца. Обухваћено је 15 појмова и 9 акронима, а сви појмови тестирани су без понуђеног контекста. Као модел истраживања послужио нам је рад Панић-Кавгић (2006), али за разлику од истраживања спроведеног у овом раду, контекст ${ }^{2}$ није играо важну улогу у нашем истраживању. Већ је и сама тема истраживања поставила одређене границе, а испитаницима је јасно указано на то да желимо испитати промене у српском језику под утицајем усменог и писаног дискурса о Европској унији, односно у светлу скорашњег почетка преговора (истраживање је спроведено током последње две недеље марта 2014, а преговори су званично отворени 21. јануара).

Нису сви појмови искључиво из домена преговора са Унијом, али су одабрани из две вишејезичне базе Канцеларије за европске интеграције Републике Србије које сматрамо да су релевантни агрегати појмова везаних за процес интеграције. Прва је Евротека, збирка

2 Панић-Кавгић (2006: 52) испитује да ли разумевање англицизама бива боље ако постоји контекст или значење и даље остаје мање или више неразумљиво. 
правних текстова и њихових сегмената, која представља двојезични корпус (текстови су на енглеском и српском језику). Израда овог корпуса је почела 2009. године и дело је преводилаца Канцеларије који марљиво преводе правне тековине ЕУ на српски језик. Друга база података је Евроним, вишејезична база термина, која се редовно ажирира и треба да послужи свима који се интересују за термине везане за процес интеграције, а којих је све више. Поред ових база, присуство скоро свих лексема је потврђено у Електронском корпусу савременог српског језика (ЕК), који уређују Природно-математички и Филолошки факултет Универзитета у Београду. Као посебна инспирација послужио је разговор аутора са чланом породице (дипломираним правником) који је открио да постоје многи изрази о Европској унији који су лако препознатљиви, али чије значење није сасвим јасно.

\section{Анализа и дискусија}

У испитивању је учествовало 22 испитаника и 28 испитаница, a распон година био је између 25 година и 63 године. Чак 47 испитаника има високу стручну спрему ${ }^{3}$ и сви су учили енглески језик на формалан или неформалан начин. Чини се да су испитаници били прилично реалистични када су оцењивали степен познавања језика па је највећи број (27) своје знање оценио као солидно, а само дванаесторо је рекло да одлично зна енглески језик. Остали сматрају да им је знање задовољавајуће. У погледу обавештености и праћења процеса интеграције путем медија или на неки други начин, можемо закључити да се ради о релативно обавештеним појединцима - њих 25 је рекло да се повремено обавести о дешавањима у овој области, 19 прати процес интеграције, а само шесторо није у току.

Резултати које смо добили у питању које се односи на то колико често се деси да испитаници не разумеју реч / израз који се односи на ЕУ, који су чули или прочитали, вредан су показатељ односа оцене знања језика испитаника и стварног стања ствари. Нешто мање од половине испитаника (22) изјавило је да се често деси да нису сасвим

3 Међу испитаницима најбројнији су били правници (8) и економисти (8), а поред њих било је политиколога (3), библиотекара и информатичара (3), психолога и педагога (3) и осталих профила које нећемо појединачно наводити. 
сигурни у значење речи или израза, а 20 је рекло да се таква ситуација дешава ретко. Могло би се рећи да се овакав резултат доводи у питање јер су одговори на питања која следе потврдили чињеницу да у великом броју случајева испитаници не знају шта заправо одређена реч или израз значи.

Питање о ставу изворних говорника о томе колико се српски језик мења под утицајем писаног и усменог дискурса о ЕУ који је обојен англицизмима дало је резултате који се поклапају са нашом почетном хипотезом. Чак 35 испитаника је рекло да сматра да се наш језик приметно мења, десеторо је рекло да се ради о незнатној промени, а нико није рекао да се језик уопште не мења. Сматрамо да је овакав податак, иако интроспективне природе, изузетно важан јер рефлектује осећај изворног говорника који је суочен са друштвено-политичким дешавањима којима неминовно мора бити сведок.

Пређимо на анализу одговора на питања у којима су испитаници показали колико познају термине који се често јављају у контексту ЕУ и процеса придруживања. Један од најпознатијих термина Уније свакако је реч француског порекла, која је у непромењеном облику ушла прво у енглески језик, а онда је из енглеског као посредника нашла место и у српском. То је синтагма acquis communautaire која се односи на све правне акте ЕУ, а у српском је прихваћен преводни еквивалент - иравне йековине ЕУ. Поред овог термина, постоји и преузета и преобликована форма - $а \kappa u$, која очито показује знаке адаптације јер се у српском деклинира и на графофонолошком плану је у складу са нормом српског језика. Међутим, значење остаје непознаница за 36 испитаника. Само 14 испитаника је препознало термин уз покушај да га дефинише. Неки од одговора били су:

„заједнички закон” ЕУ; скуп правних аката ЕУ; Односи се на заједничко европско законодавство. Не знам одговарајући српски термин; Чула сам за реч, али не бих знала прецизно да кажем шта значи. Мислим да се везује за државни правни систем.

Израз је потврђен у ЕК, а у неколико случајева термин је апозицијом детаљније појашњен, што говори о томе да је писац свестан да је термин нов и да може изазвати забуну код читаоца: 
Од тренутка закључивања споразума са Унијом почиње, пак, да тече и наша обавеза усвајања тзв. „аки комунитера", односно правног поретка ЕУ. . . (Политиика, 2007)

Премијер Цветковић ће данас у Загребу у Банским дворима имати и сусрет са представницом Владе Хрватске Јадранком Косор, која ће му том приликом уручити хрватски превод правних тековина ЕУ, такозвани „аки комунотер”. (Полиииика, 2010)

Парадоксално је да Србија можда неће ући заједно са Хрватском него нешто касније, иако предњачи у испуњавању аки комунитера. (Политиика, 2009.)

Лакше је било са појмовима који су се, изгледа, одомаћили у српском јер их само осам испитаника није препознало. У питању су термини $g u$ рекийва и уреgба. У овом случају не можемо говорити о англицизмима јер се ове речи употребљавају и у српском, нарочито друга. Дирекииива је преузела облик енглеске речи directive, а уреgба је прихваћена после краће потраге за најбољим еквивалентом. Наиме, у документима који су се преводили и о којима се говорило и писало пре десетак година могла се срести и реч реїулатиива, која је требало да попуни лексичку празнину у српском језику уместо енглеске речи regulation. Међутим, постојећа српска реч је само попримила део значења који раније није имала и постала је достојна замена за енглески термин. Дакле, у питању је семантичко позајмљивање (Филиповић 1986: 153) или семантичко калкирање (Хлебец 2009), односно пренос значења из језика даваоца на јединицу у језику примаоцу која је већ постојала. Насупрот овом процесу била би адаптација значења речи из језика даваоца, која се врши тек пошто је позајмљеница већ ушла у језик прималац. Међутим, иако је више од 80 \% испитаника изјавило да зна шта ови појмови значе, недостајала је прецизност јер је веома мали број испитаника знао тачну дефиницију. У већини случајева испитаници су знали надређени појам, што је довољно за оријентацију у дискурсу. Најпотпунији одговор је гласио:

Примарно законодавство ЕУ. Уредбе се директно примењују у државама чланицама, а директиве је могуће прилагодити националним правним прописима тако да се не мења суштина директиве.

Један од важних корака у придруживању је и йрансйозищија, односно, како стоји у Еврониму, „уношење (у национални правни си- 
стем)". Мисли се, наравно, на усаглашавање националног законодавства са законодавством ЕУ. Само 14 испитаника није знало о чему се ради, а покушаји објашњења термина били су прилично успешни.

Још један термин за који се на основу бројки може закључити да је већина испитаника препознала био је демокрайски gефиций. Само 11 испитаника написало је да не зна шта ова синтагма значи. Међутим, анализом одговора, закључујемо да се ради о директном преводу и учитавању значења од стране испитаника на основу појмова који су дубље укорењени у наш систем, попут буцейскої geфиичй $а$. Ипак, демократски дефицит није само прост „мањак демократије” или „непоштовање демократских начела”, како је велики број испитаника написао, већ представља појам који се нарочито у оквиру ЕУ доводи у везу са питањем оправданости гломазног апарата ЕУ и места појединца у ланцу одлучивања. Издвајамо најбоље објашњење које је један испитаник понудио:

У најкраћем: недовољно учешће грађана у институцијама власти, недоступност власти грађанима, као и неразумљивост и превелика бирократизација институција власти.

Два су појма међу испитаницима прошла „неславно”, а то су начело суйсияијарносиии и флексиіурносй. Први појам није препознало 33, а други чак 47 испитаника. Они заиста јесу мање прозирни и ређе се помињу у медијима, а флексиіурности је у ЕК потврђена само једним примером и то претраживањем изворног термина flexicurity:

Ако је раније било важно обезбедити сигурност радних места, данас је важно обезбедити сигурност радника, пре свега, могућност њихове преквалификације. То се назива flexicurity (флексибилност и сигурност). (Политиика, 2009)

У овом примеру појам се објашњава тако што се развија у две

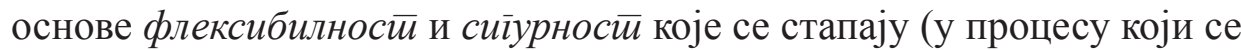
још назива и конфлација) и стварају такозвану сливеницу или бленду. Овакав успешан пренос творбеног обрасца са једног на други језик могао би се објаснити заједничким кореном обе речи из латинског језика. Претраживањем Интернета наишли смо на значајан број текстова у којима се употребљава појам флексиіурносй, али искључиво у хрватском језику, што се може објаснити чињеницом да је Хрватска већ постала чланица ЕУ и да су у њој реформе почеле раније него 
у Србији па се и радно право реформисало у складу са захтевима и начелима ЕУ. О суйсияијарносӣи је тешко доносити закључке јер је ово заиста ускостручан термин па су га правници међу испитаницима најбоље разумели. Изгледа да је тешко сковати синтагму од два члана на српском која би пренела садржај овог појма, па бисмо могли констатовати да је ова делимична позајмљеница (због тога што је употребљен одговарајући кореспондент речи principle - начело) оправдана. Један испитаник је на врло једноставан начин објаснио о чему се заправо ради кад се помене овај термин:

Доношење одлука на што нижем нивоу организације, тј. приближавање одлучивања о заједничким питањима обичном човеку.

За разлику од појма имйлеменйација код кога се примећује све већа тенденција замене једним од могућих кореспондената у српском језику (спровођење, реализација, примена), појмови ауйсорсині и стиејкхолgер се и даље осећају бољим варијантама него српски преводни еквиваленти, који би у најбољем случају били описни преводи. Чини се, међутим, да су заиниеересоване сииране почеле да потискују стиејкхолgере, нарочито када се овај термин јавља у политичком домену. Код економиста, међутим, енглески појам се сматра адекватнијим. Укупно гледано, више од половине испитаника (27) бира англицизам уместо српске варијанте, која у кондензованом облику, морамо бити реални, не постоји за ауйсорсині јер овај појам подразумева не само „коришћење спољних средстава”, „поверавање активности трећем лицу” или „ангажовање спољних сарадника”, већ и економски елемент који се помиње у одговору једног испитаника - „премештање посла на страна тржишта (најчешће због јефтине радне снаге)”.

Утицај медија на језичку културу огледа се на примеру појма $O M$ буgсман, који је преузет из енглеског посредно јер је извориште овог појма у шведском језику. Овај појам препознало је највише испитаника, чак $90 \%$, а скоро сви су знали да је у питању зашимийник иррава ірађана. Омбуgсман се не може прогласити англицизмом, а може се класификовати и као име институције, тачније института у правном смислу, тако да се позајмљивање ове врсте може толерисати. Међутим, очигледно је да постоји адекватан функцијско-комуникативни еквивалент у српском језику и можда би било боље држати се домаћег облика.

Сличан статус има и појам Генерални gирекӣорай који је преузет из енглеског који има улогу језика посредника. Изворни облик је 
француског порекла, а енглески је направио калк па је због тога придев у постпозицији, што за енглески није типично, али јесте за француски - Directorate-General. Пошто се ради о називу делова Европске комисије у оквиру Уније, можемо констатовати да је овај термин најбоље преузети. Штавише, у српској варијанти, придев је померен на позицију која одговара норми и термин је адаптиран у сваком погледу.

Важно је поменути да је највише покушаја објашњења појма дато за појам ексйланайорни скринині, чије значење је мислило да познаје 28 испитаника. Анализом одговора, закључујемо да велики број објашњења не одговара намераваном значењу овог термина, који је један од најновијих европских термина у српском језику. Најбоље су термин схватили инспитаници који су навели следеће:

Аналитички приказ законодавства ЕУ, тј. европски експерти објашњавају своје законодавство; Аналитички преглед и оцена усклађености националног законодавства са правним тековинама ЕУ. Састанак у оквиру кога експерти ЕУ члановима преговарачких група представљају законодавство ЕУ из одређене области; Прва фаза у процесу преговора где Европска комисија износи правне тековине ЕУ држави кандидату.

Ово је један од термина који ће вероватно такав и остати у српком језику, адаптиран на графофонолошком плану, али значење ће остати нејасно све док се у медијима не устали у довољној мери и док не постане саставни део свакодневне политике. У медијима и званичним документима преговарачкиг тела као еквивалент појаљује се аналийички ирреілес йройиса.

Термин који се такође појавио са почетком преговора је и бенчмаркині, који су многи испитаници препознали захваљујући знању из економије и менаџмента где се бенчмаркині користи да упути на „поређење са конкуренцијом или са 'best practice'”, „смерницу или репер”, „производ који поставља стандарде”. Једноставно речено, то су главни показатељи или мерила на основу којих држава која преговара са ЕУ треба да уреди своје законодавство. Верујемо да ће бенчмарк, и бенчмаркині бити кратког даха у српском језику и да ће се употреба мерила и фразе усйосйављағе мерила показати као природније варијанте.

Пре него што пређемо на категорију акронима, погледајмо још један случај англицизма који сматрамо да се неоправдано користи јер 
постоји домаћи еквивалент. Гранйови ЕУ су заправо бесйоврайна йомоћ, и то је оно што грантове разликује од кредита или стипендија. Испитаници су углавном могли да одреде домен из ког потиче овај појам па су помињали да се појам односи на „финансирање пројеката”, „зајмове ЕУ”, „финансијску помоћ”, „финансијска средства намењена за одређене пројекте" итд.

У четири питања / задатка тестирали смо познавање 9 акронима који се често срећу у писаном и усменом дискурсу о Европској унији. Прћић (2005: 220) акрониме или иницијализме дефинише као ,лексичке јединице настале издвајањем почетних слова, једног или више њих, из дугачких и гломазних лексичких јединица, у циљу њиховог скраћивања". Акроними у језику примаоцу често бивају лексикализовани и препознају се као просте речи, као што је, на пример, случај са називом организације Уницеф која се третира као проста именица. Међутим, акроними су углавном ограничени на ужу област из које су потекли па се њихов статус стране речи дуго задржава. Акронимија је типична у случајевима када се називи организација и институција скраћују да би се лакше изговарали и писали, а такви називи по природи ствари имају статус страног властитог имена. Ми смо тестирали акрониме са намером да проверимо не само познавање пуног облика, већ и начин писања префиксоида евро- и устаљеност акронима, односно степен његове лексикализованости у српском језику. У Приручнику за ирревођење ирравних акайа Евройске уније (2012: 104) стоји напомена да се очекује да ће велики број акронима, који се стално стварају, ући у српски језик у процесу превођења правних аката ЕУ, што може послужити као позив свима који се баве превођењем и језичком културом да се озбиљно позабаве питањем акронима.

Табела 1 приказује акрониме који су употребљени у истраживању и њихове пуне облике у оригиналу, као и прихваћени превод у српском језику. Превод и облици акронима на српском језику преузети су из Приручника (2012: 104-123), а ваљало би напоменути да на списку акронима нема акронима ИПА, који се прилично одомаћио у нашем језику и који је документован у ЕК, али са ограниченом адаптацијом јер се не деклнинира, а и употребљава се према синтаксичком моделу из енглеског - у именичкој синтагми где ИПА има функцију модификатора испред управне речи. 
Европске паре помоћи се и реконструкцију Жежељевог моста. Из ИПА 2009. за ту намену одвојено је 30 милиона евра. (Полийика, 2010)

Србија данас има право да користи новац из два, од пет делова ИПА фонда - за помоћу транзицији и изградњу институција, као и за прекограничну сарадњу. (Полиииика, 2010)

У 2010. Години, Србија је добила 20 милиона евра бесповратних средстава ЕУ у оквиру ИПА пројеката за развој информационог друштва и дигитализацију телевизије. (www.rts.rs, 2010)

\section{Табела 1}

\begin{tabular}{|c|c|c|c|}
\hline $\begin{array}{l}\text { Енглески } \\
\text { акроним }\end{array}$ & $\begin{array}{l}\text { Пун облик на } \\
\text { енглеском }\end{array}$ & $\begin{array}{l}\text { Српски } \\
\text { акроним }\end{array}$ & Пун облик на српском \\
\hline CEFTA & $\begin{array}{l}\text { Central European Free } \\
\text { Trade Agreement }\end{array}$ & ЦЕФТА & $\begin{array}{l}\text { Споразум о слободној } \\
\text { трговини у централној } \\
\text { Европи }\end{array}$ \\
\hline ECOFIN & $\begin{array}{l}\text { Council of Economic } \\
\text { and Finance Ministers } \\
\text { (Economic and Finan- } \\
\text { cial Affairs Council) }\end{array}$ & ECOFIN $^{4}$ & $\begin{array}{l}\text { Савет министара економије } \\
\text { и финансија (Савет за } \\
\text { економске и финансијске } \\
\text { послове) }\end{array}$ \\
\hline IPA & $\begin{array}{l}\text { Instrument for Pre-Ac- } \\
\text { cession Assistance }\end{array}$ & ИПА & $\begin{array}{l}\text { Инструмент за } \\
\text { претприступну помоћ }\end{array}$ \\
\hline SAA & $\begin{array}{l}\text { Stabilization and As- } \\
\text { sociation Agreement }\end{array}$ & ССП & $\begin{array}{l}\text { Споразум о стабилизацији и } \\
\text { придруживању }\end{array}$ \\
\hline EP & European Parliament & ЕП & Европски парламент \\
\hline COREPER & $\begin{array}{l}\text { Committee of Perma- } \\
\text { nent Representatives }\end{array}$ & КОРЕПЕР & $\begin{array}{l}\text { Комитет сталних } \\
\text { представника }\end{array}$ \\
\hline TEMPUS & $\begin{array}{l}\text { Trans-European Co- } \\
\text { operation Scheme for } \\
\text { Higher Education }\end{array}$ & ТЕМПУС & $\begin{array}{l}\text { Трансевропски програм } \\
\text { сарадње у области високог } \\
\text { образовања }\end{array}$ \\
\hline Europol & European Police Office & Европол & $\begin{array}{l}\text { Европска полицијска } \\
\text { канцеларија }\end{array}$ \\
\hline Eurostat & $\begin{array}{l}\text { Statistical Office of the } \\
\text { European Union }\end{array}$ & Евростат & $\begin{array}{l}\text { Статистички завод Европске } \\
\text { уније }\end{array}$ \\
\hline
\end{tabular}

4 Овај акроним се у Приручнику наводи у изворном облику. У ЕК потврђена је употреба лексикализованог облика који се деклнинира и пише двојако ЕКОФИН и Екофин. 
У погледу акронима, резултати показују да се акроними који се већ дуже време употребљавају и медијски експонирају третирају као лексикализоване речи мада прецизност у навођењу пуног облика није нарочито велика. Највећи број испитаника је препознао Цефйу (39), али нису били сигурни који је пун назив, 28 испитаника је препознало ИПУ, следећи је био ЕП - 26 испитаника је знало о којој институцији се ради, док је најнепрозирнији био Екофин који је препознало само 17 испитаника. Замнимљиво је да је чак 23 од 28 испитаника који су чули за ССП навело тачан назив Споразума, а остали су незнатно одступили од пуног облика. Овај податак говори о томе да је ССП добио статус непрозирне речи, а томе је највероватније допринело и то што је Споразум био један од великих догађаја везаних за европску будућност Србије и што је потписан још 2008. године. ТЕМПУС је препознало 24 испитаника и сви су знали да је овај програм из области образовања. За КОРЕПЕР је знало само 8 испитаника, што говори о специфичности термина и слабој заступљености у медијима.

У жељи да сазнамо како говорници српског језика третирају префиксоид евро-, облик који је препоручио Одбор за стандардизацију српског језика, тестирали смо неколико акронима. До данашњег дана питање изговора овог префиксоида, чини се, није сасвим решено. И даље се у медијима чује и пише „еуро” за назив валуте. Овим питањем бавио се и Фекете (2006: 109-111) наводећи разлоге због којих би се облик еуро можда и могао размотрити као оправдан назив имена валуте Европске монетарне уније. Он помиње да је још 1999. године на међубанкарском састанку заузет став да се валута назива еуро, док Павле Ивић, тадашњи председник Одбора за стандардизацију, у Полиииици (6. јануара 1999, стр. 8) предлаже да се усвоји облик евро због етимолошке везе са називом Евройа. У нашем испитивању приметили смо да ово питање још увек није решено, али превагу је ипак однео облик евро-. Облик са префиксоидом евро- одабрало је 37 $(\text { Евробарометар })^{5}, 31$ (Европол) и 31 (Евростат) испитаник, али су

5 Овај облик није стриктно гледано акроним, али смо га употребили због префиксоида евро-. Приручник (2012: 127) овај облик сврстава у еврожаріон, „Посебан језик, или, још прецизније, терминологију коју користе европски политичари и новинари када говоре о ЕУ (а која се потом користи и у правним актима ЕУ)”. 
били несигурни у вези са значењем акронима. На пример, да се Евробарометар односи на истраживање јавног мњења грађана Европске уније није знало чек 35 испитаника.

\section{Закључак}

Шта можемо закључити о српском језику који је заједно са својим народом кренуо пут европских интеграција? Пре свега, утицај дискурса о Европској унији представља само један од фактора дијахронијских помака који се примећују у српском језику. Овај дискурс је по својој природи „англицизиран” па се и у српски језик речи преузимају или директно из енглеског извора или посредним путем када енглески игра улогу преносника језичких елемената неких других језика, као што су у нашим примерима француски или шведски. Утицај медија и развој информационо-комуникацијских технологија додатно утичу на језичке промене које су у директној спрези са друштвено-политичким дешавањима. Наше истраживање је управо показало да се одређени термини који се већ неко време користе у усменом и писаном дискурсу препознају лакше од оних који су ускостручни и ређе експонирани у јавности.

Међутим, иако су промене неминовне, и тога је велика већина испитаника свесна, поставља се питање да ли можемо учинити нешто да се позајмљивање и преузимање страних елемената врши на језику природан начин. Овде мислимо на преузимање речи само ако у српском постоји права лексичка празнина и ако језички механизми попут превођења семантичког садржаја и преузимања страних творбених образаца уз коришћење домаћих елемената не уроде плодом. Свакако да ће се терминолошка база речи које се везују за европску интеграцију увећавати из године у годину, али треба размишљати и о сасвим обичним говорницима српског језика који треба да одрже корак са језичким променама које захваљујући медијима наступају необично брзо. Видимо да се и после петнаест година и даље двоумимо око употребе префиксоида евро-, произвољно употребљавамо и имйлеменйацију и сировођење, а код неких новијих појмова, као што је ексйланайорни скринині, можемо само да застанемо и да покушамо да дођемо до значења преко контекста. 
Стога сматрамо да је веома важно пратити промене у језику и бити свестан да сваки изворни говорник употребом језика чини да оно што се у њему појави преко ноћи заживи и остане у језику и за наредне генерације. Зато није лоше бити и помало критичан према новим елементима, не зато што хоћемо у стилу пуризма да протерамо све што није домаће, већ зато да би језику помогли да на природан начин настави своје постојање и одржи свој идентитет.

\section{Додатак}

Упитник који је пред Вама послужиће као полазиште истраживања које би требало да буде представљено на научном скупу на Филолошком факултету Универзитета у Београду. Упитник је анониман и не треба га схватити као испит знања о Европској унији, већ као показатељ промена у српском језику под утицајем друштвено-политичких дешавања. Стога Вас молим да на питања одговорите искрено и на основу Ваших сазнања (без консултовања Интернета, приручника или туђег мишљења), не оптерећујући се исправношћу одговора.

Молим Вас да на питања одговарате подвлачењем жељеног одговора опцијом $\mathrm{Ctrl}+\mathrm{U}$ и / или укуцавањем одговора директно иза питања. Ако немате одговор на питање, напишите: „Немам одговор”. Молим Вас да све промене на крају сачувате кликом на одговарајућу иконоцу или опцијом $\mathrm{Ctrl}+\mathrm{S}$.

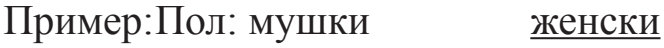

Занимање: правник/ца

Унапред Вам најискреније захваљујем на помоћи и сарадњи!

Пол: мушки женски

Година рођења:

Занимање:

Образовање:

a) основна школа

б) средња школа или гимназија

в) виша школа 
г) висока школска спрема (*специјалистичке студије / мастер / магистратура / докторат)

(*Подвуците последњи, односно највиши степен.)

Да ли сте икада на формалан или неформалан начин учили енглески језик?

Да. Не.

Како процењујете своје знање енглеског језика у смислу разумевања писаног и усменог садржаја?

a) Одлично је.

б) Солидно је.

в) Задовољавајуће је.

г) Слабо је.

д) Нити користим нити разумем енглески језик.

1. Дали захваљујући медијима или на било који други начин пратите процес преговора Србије са ЕУ?
a) Да.
б) $\mathrm{He}$.
в) Повремено се обавестим.

2. Колико често се деси да прочитате или чујете неку реч или израз везан за ЕУ који не разумете најбоље?
a) Никада.
б) Врло ретко.
в) Ретко.
г) Често.
д) Врло често.

3. Да ли сматрате да се српски језик мења под утицајем „новијег“ (писаног и усменог) дискурска о ЕУ у којем се јављају појмови махом из енглеског језика?
а) Да, приметно се мења.
б) Незнатно се мења.
в) Уопште се не мења.
д) Немам одређено мишљење. 
4. Да ли сте се некада срели са појмом аки (према: acquis communautaire)? Да. Не.

Ако јесте, на шта се он односи и да ли постоји прихваћени српски термин?

5. Ако препознајете скраћенице које се користе у контексту ЕУ, молим Вас напишите пун назив сваког појма или макар напишите на шта се он односи:

ЦЕФТА -

$\mathrm{E} \Pi-$

ЕКОФИН ${ }^{6}-$

ИПА-

ССП (према енглеском $S A A)$ -

6. На коју област се односи скраћеница ТЕМПУС?

7. У светлу преговора Србије са ЕУ, шта за Вас значи ексйланаиоорни скрининї?

8. На шта се односи појам бенчмаркині̄?

9. Имајући у виду енглеску реч implementation, који термин употребљавате када се говори о законским прописима?

а) имплементација

б) спровођење

в) примена

10. Шта су gирекиииве и уреgбе ЕУ ЕU?

11. Шта заправо значи йрансйозищија права ЕУ у национално законодавство?

12. Једно од основних начела ЕУ је начело суйсияијарносӣи. На шта се оно односи?

6 Овај акроним најчешће се у српском јавља исписан латиничним писмом и то у изворном енглеском облику - ECOFIN. Ћирилицом га исписују у Бугарској и у Босни и Херцеговини. У упитнику био је исписан у изворном облику. 
13. Како разумете појам демокрайски gефициий?

14. Подвуците облик за који сматрате да је исправан са становишта норме и правописа српског језика, па у наставку напишите на шта се скраћенице односе:

Еуробарометар или Евробарометар -

Европол или Еуропол -

Еуростат или Евростат -

15. Да ли постоји домаћа реч или израз за појам Омбуgсман? Да. Не.

Ако мислите да постоји, понудите израз:

16. Када кажемо ірранйови $E У$, на шта тачно мислимо?

17. У саставу којег тела ЕУ се налазе Генерални gирекйорайи?

Да ли бисте предложили другачији превод енглеског појма Directorate-General?

18. Које бисте речи на српском употребили уместо понуђених речи преузетих из енглеског језика?

ауйсорсині (према: outsourcing) стиејкхолgер (prema: stakeholder) Коју варијанту радије користите?

a) Ону преузету из енглеског.

б) Домаћу (ако је познајете).

19. Да ли сте упознати са термином Кореиеер (према оригиналном COREPER)?

Да. Не.

20. Да ли сте се некада срели са појмом флексиіуурност̄ (према: flexicurity)?

Да. Не.

Ако јесте, на коју област социјалне политике се он односи? 


\section{Извори}

Канцеларија Републике Србије за европске интеграције - http://www. seio.gov.rs (март 2014.)

Евроним - http://prevodjenje.seio.gov.rs/evronim/index.php?jezik=srpl (фебруар-март 2014.)

Евротека - http://prevodjenje.seio.gov.rs/evroteka/index.php?jezik=srpl (фебруар-март 2014.)

Електронски корпус савременог српског језика - http://www.korpus. matf.bg.ac.rs/korpus/login.php (фебруар-март 2014.)

\section{Литература}

Фекете 2006: Егон Фекете. Језичке gоумице: новије и стиарије. Друго издање. Београд: Београдска књига, 109-111.

Филиповић 1986: Рудолф Филиповић. Теоријајезика у конйакӣу. Увоg y линівистиику језичних gоgира. Загреб: Југославенска академија знаности и умјетности, Школска књига.

Хауген 1956: Einar Haugen. Bilingualism in the Americas: A Bibliography and Research Guide. Alabama: The American Dialect Society. (2. издање 1964).

Хлебец 2009: Хлебец, Борис. Превоgилачке иеехнике и йосийуйи \{енілески језик\}. Београд: ЕБГ, 2009.

Канцеларија за европске интеграције и Републички секретаријат за законодавство. Приручник за йревођене йравних акайа Евройске уније.Треће, измењено и допуњено издање. Београд: Република Србија, Влада, Канцеларија за европске интеграције, 2012.

Панић-Кавгић 2006: Олга Панић-Кавгић. Колико разумемо нове анїлицизме. Нови Сад: Змај.

Прћић 2005: Твртко Прћић. Еніллески у срӣском. Нови Сад: Змај, 2005. Шипка 2006: Данко Шипка. Основи лексиколойије и сроgних gисиийлина. Нови Сад: Матица српска.

Васић, Прћић и Нејгебауер 2011: Вера Васић, Твртко Прћић, и Гордана Нејгебауер. Do уи speak anglosrpski? Речник новијих анїлииизама. Друго издање. Нови Сад: Змај, 2011. 
Ana Tomović

\section{Summary \\ THE SERBIAN LANGUAGE ON ITS ROAD TO THE EUROPEAN UNION}

This paper deals with the impact that the recent, oral and written, European Union discourse has had on the Serbian language. It has been two years since Serbia gained the official membership candidate status and more than two decades since the biggest enlargement took place. However, the EU topics and the discourse on the EU are very much alive and Serbian has been awash with new concepts mainly from English acting as a source language but as an intermediary as well. The aim of the research was to determine how much of the meaning of the new loanwords stays undisclosed by the average, fairly educated and more or less informed native speaker of Serbian. The well-adapted loans were observed as well because, even though they have become part of Serbian, they still seem to confuse many native speakers. We based our research on a questionnaire which was filled in by 50 native speakers of Serbian of different sex and age. After a thorough analysis of the responses has been done, one can safely say that the Serbian language is perceived to be changing under the new social and political circumstances. The respondents confirmed out initial thesis - that there are still quite a few loanwords, the meaning of which native speakers are unsure of and which have exercised a major impact on the Serbian lexis. We also shed light on some orthographic issues as well as the adaptation processes some of the words and expressions have gone through.

Key words: Serbian, English, borrowings, mediating language, EU discourse, socio-political circumstances 